\title{
The pH partition theory predicts the accumulation and toxicity of doxorubicin in normal and low-pH-adapted cells
}

\author{
LE Gerweck, SV Kozin and SJ Stocks \\ Department of Radiation Oncology, Massachusetts General Hospital, Boston, MA 02114, USA
}

\begin{abstract}
Summary The accumulation and toxicity of the weak base doxorubicin has been investigated as a function of extracellular $\mathrm{pH}$, intracellular $\mathrm{pH}$ and the cellular $\mathrm{pH}$ gradient in cells previously cultured under normal $(\mathrm{pH} 7.4)$ and low-pH (6.8) conditions. Low-pH-adapted cells exhibit transmembrane $\mathrm{pH}$ gradients which substantially differ from normal cells at the same extracellular $\mathrm{pH}$. No relationship was obtained between intracellular $\mathrm{pH}$ and the uptake or toxicity of doxorubicin in the two cell types. In contrast, doxorubicin accumulation and toxicity increased with increasing extracellular $\mathrm{pH}$ in both normal and low-pH-adapted cells. However, at the same extracellular pH, drug cytotoxicity was more pronounced in normal than in low-pH-adapted cells. The difference in doxorubicin accumulation and cytotoxicity at the same extracellular pH was found to be dependent on the difference in the transmembrane $\mathrm{pH}$ gradient of the two cell types. As the cellular $\mathrm{pH}$ gradient differs between tumour and normal tissue, this observation suggests a basis for enhancing cellular drug uptake in either tissue type.
\end{abstract}

Keywords: pH; pH gradient; doxorubicin; cellular toxicity; cellular accumulation

The cytotoxicity of doxorubicin is strongly influenced by variation in extracellular $\mathrm{pH}$ (Born and Eichholtz-Wirth, 1981). As is the case with other weak electrolytes (Brophy and Sladek, 1983; Dennis et al, 1985; Mikkelsen et al, 1985; Skovsgaard, 1977), this variation in toxicity may be due to a $\mathrm{pH}$-dependent shift in the ratio of the ionized to non-ionized form of this weak base. In its non-ionized form, the lipophilicity of weak electrolytes is increased, thereby enhancing their diffusion through the cell membrane to an intracellular site of action. Extensive investigation of the mechanism of doxorubicin uptake indicates that passive diffusion of the non-ionized form of the drug is the most likely explanation for the $\mathrm{pH}$-dependent modification of cellular drug uptake (and by implication, cytotoxicity), but that carrier-mediated uptake cannot be excluded with the specificity or efficiency of the carrier being dependent on the ionization status of the drug (Skovsgaard, 1977). The toxicity of a number of drugs is sensitive to variation in $\mathrm{pH}$ by various mechanisms which are not dependent on ionization-dependent diffusion through the cell membrane (Jähde et al, 1989; Skarsgard et al, 1995). For example, extracellular $\mathrm{pH}$ variation substantially modifies the toxicity but not the cellular uptake and accumulation of the actively transported drug melphalan (Skarsgard et al, 1995). Additionally, it has been reported that the cytotoxicity of free doxorubicin is identical to doxorubicin bound to large particles excluded by the cell (Tritton and Yee, 1982). These results suggest an extracellular (membrane) site of doxorubicin action, i.e. with toxicity not being dependent on drug uptake.

To the extent toxicity is dependent upon the intracellular accumulation of doxorubicin, variation in $\mathrm{pH}$ and its resultant effect on

Received 29 April 1998

Accepted 24 July 1998

Correspondence to: LE Gerweck drug charge and membrane diffusion would affect the drug's intracellular concentration and therefore its toxicity (Eichholtz-Wirth, 1980). In theory, at steady state, the intravesicular concentration of a weak electrolyte which is impermeable in its charged form, but membrane permeable in its uncharged form, is dependent upon the magnitude of the $\mathrm{pH}$ gradient across the cell membrane and the drug $\mathrm{pKa}$ (Roos and Boron, 1981). This has important implications for the differential uptake and potentially the toxicity of weak electrolytes, such as doxorubicin, in tumour and normal tissue. Although the intracellular $\mathrm{pH}$ of tumour and normal tissue is similar, the extracellular $\mathrm{pH}$ of human tumours is more acidic than normal tissues, giving rise to substantially different cellular $\mathrm{pH}$ gradients in these tissues (Vaupel et al, 1989; Gerweck and Seetharaman, 1996).

To evaluate the role of extracellular and intracellular $\mathrm{pH}$ and the $\mathrm{pH}$ gradient on doxorubicin accumulation and cytotoxicity, studies were conducted on normal and low-pH-adapted Chinese hamster ovary cells in vitro. As previously described, low-pH-adapted cells are resistant to changes in intracellular $\mathrm{pH}$ upon reduction of extracellular pH (Kozin and Gerweck, 1998). Therefore, at a particular extracellular $\mathrm{pH}$, different $\mathrm{pH}$ gradients are obtained in the two cell types, whereas at a similar intracellular $\mathrm{pH}$ the extracellular $\mathrm{pH}$ substantially differs.

\section{MATERIALS AND METHODS}

\section{Cell culture}

Chinese hamster ovary cells were cultured and studied in Ham's F-12 medium supplemented with $12 \%$ fetal bovine serum plus antibiotics. The medium was buffered with $15 \mathrm{~mm}$ Hepes, $10 \mathrm{~mm}$ EPPS, plus approximately $3 \mathrm{~mm}$ sodium bicarbonate from the serum. Medium $\mathrm{pH}$ was adjusted with $1 \mathrm{~N}$ hydrochloric acid or $1 \mathrm{~N}$ sodium hydroxide at $37^{\circ} \mathrm{C}$. Cells were grown as subconfluent monolayers and transferred twice per week. Normal cells were 
cultured in medium adjusted to $\mathrm{pH} \mathrm{7.4,} \mathrm{and} \mathrm{acid-adapted} \mathrm{cells}$ continuously cultured ( $>2$ months) in medium adjusted to $\mathrm{pH} 6.8$. During culture, the $\mathrm{pH}$ of the medium decreased by approximately $0.2 \mathrm{pH}$ units over 3-4 days in both cell types. The doubling times of the normal and acid-adapted cells were similar, i.e. 13-14 and 14-15 h respectively. All experimental studies were performed on exponentially growing cells.

\section{Measurement of intracellular $\mathrm{pH}$}

Intracellular $\mathrm{pH}$ was evaluated by the method originally developed by Waddell and Butler (1959), which is based on the equilibrium distribution of the weak acid $\left[{ }^{14} \mathrm{C}\right] \mathrm{DMO}\left(\left[2-{ }^{14} \mathrm{C}\right] 5,5\right.$-dimethyl-2,4oxazolidinedione) across the cell membrane. This technique, with some modification, has frequently been used by others and is described in detail elsewhere (Chu and Dewey, 1988; Fellenz and Gerweck, 1988; Kozin and Gerweck, 1998). Briefly, trypsinized cell suspensions $\left(5-10 \times 10^{5}\right.$ cells $\left.\mathrm{ml}^{-1}\right)$ were concurrently labelled with $\left[{ }^{3} \mathrm{H}\right]$ water and $\left[{ }^{14} \mathrm{C}\right] \mathrm{DMO}$ or $\left[{ }^{14} \mathrm{C}\right]$ inulin. Twenty to thirty minutes after the adjustment of the extracellular $\mathrm{pH}\left(\mathrm{pH}_{\mathrm{e}}\right)$, samples of the suspension were centrifuged through $0.2 \mathrm{ml}$ of silicone oil into $0.06 \mathrm{ml}$ of $0.8 \mathrm{M}$ perchloric acid. Aliquots of the supernatant and perchloric acid cell extracts were removed for determination of total and extracellular water and intracellular and extracellular DMO. These data were used to calculate intracellular $\mathrm{pH}\left(\mathrm{pH}_{\mathrm{i}}\right)$ at various $\mathrm{pH}_{\mathrm{e}}$ (Kozin and Gerweck, 1998).

\section{Measurement of cellular doxorubicin}

Cell suspensions $\left(5-10 \times 10^{6}\right.$ cells $\left.\mathrm{ml}^{-1}\right)$ were prepared in medium at the appropriate $\mathrm{pH}$, brought to $37^{\circ} \mathrm{C}$ and spiked with doxorubicin (doxorubicin hydrochloride VHA, Irving, TX, USA) also prepared in $\mathrm{pH}$-adjusted medium to yield a final concentration of $10 \mu \mathrm{g} \mathrm{ml}^{-1}$. The suspension was continuously agitated with a reciprocal shaker, and $1-\mathrm{ml}$ samples were periodically removed for up to $100 \mathrm{~min}$. The sample was layered on the top of a two-phase combination of silver nitrate $(5.5 \%, 100 \mu 1$, lower phase) (Schwartz, 1973) and silicone oil ( $200 \mu \mathrm{l}$, upper phase) in a polypropylene microcentrifuge

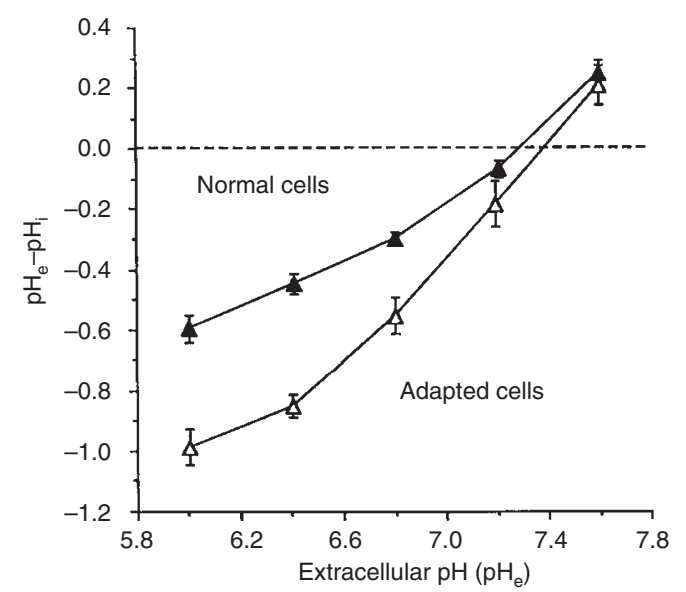

Figure 1 The difference between the intracellular and extracellular $\mathrm{pH}$ $\left(\mathrm{pH}_{-}-\mathrm{pH}_{\mathrm{i}}\right)$ is plotted as a function of extracellular $\mathrm{pH}$ for normal and low-pHadapted cells. Each data point is the mean and s.d. of 12 sample assays from three independent experiments. Intracellular $\mathrm{pH}$ values were determined at 20-30 min after adjustment of extracellular $\mathrm{pH}$. Confidence intervals of extracellular $\mathrm{pH}$ values are $\leq 0.05$ units tube, and immediately centrifuged. The upper medium layer was sampled for measurement of extracellular doxorubicin. The pellet was resuspended in the silver nitrate solution and extracted for $30 \mathrm{~min}$ at $0^{\circ} \mathrm{C}$. The silver nitrate extract and medium were further extracted with chloroform/methanol (9:1), dried over nitrogen, and dissolved in $100 \mu \mathrm{l}$ formate buffer $(0.1 \%$ ammonium formate, $\mathrm{pH}$ 4.0) for high-performance liquid chromatography (HPLC) analysis (Israel et al, 1978). Samples (35-75 $\mu 1)$ were separated on a $150 \times 0.9 \mathrm{~mm}$ i.d. column containing a $\mathrm{C}_{18} 5-\mu \mathrm{m}$ silica particle stationary phase and a mobile phase of $0.1 \%$ ammonium formate, $\mathrm{pH}$ 4, and acetonitrile (3:1), at a flow rate of $0.6 \mathrm{ml} \mathrm{min}$. Doxorubicin was quantitated by area under the curve absorbance at $479 \mathrm{~nm}$ compared with known concentrations of doxorubicin. Doxorubicin metabolites were not detected. The HPLC measurements yielded the total extracted cellular concentration of doxorubicin and the adhering fluid layer surrounding the cells. The size of the extracellular compartment was determined by analysis of the fraction of total water per cell $\left(\left[{ }^{3} \mathrm{H}\right]\right.$ water $)$ and extracellular water $\left(\left[{ }^{14} \mathrm{C}\right]\right.$ inulin). After adjusting for doxorubicin contained in the adherent extracellular water space, the doxorubicin concentration per unit cell water was calculated.

\section{Evaluation of drug cytotoxicity}

Doxorubicin was freshly diluted in medium at the appropriate $\mathrm{pH}$ before use and added to single cell suspensions $\left(2 \times 10^{5}\right.$ cells ml-1) at $\mathrm{pH} 7.4,6.8$ or $6.4( \pm 0.05)$. Cells were incubated for $90 \mathrm{~min}$ at $37^{\circ} \mathrm{C}$ with gentle continuous agitation on a reciprocal shaker.

After drug treatment, the cells were centrifuged, washed twice with drug-free medium and seeded in $25 \mathrm{~cm}^{2}$ plastic flasks to yield 50-200 colonies. Four to six flasks were used for each data point. Medium at $\mathrm{pH} 7.4$ was used for washing and cloning of normal cells, and pH 6.8 medium was used for acid-adapted cells. After incubation, the colonies were stained and counted. Cell survival was calculated as the ratio of the number of colonies divided by the number of cells plated in treatment vs control flasks. In the absence of drug treatment, the plating efficiency was close to $100 \%$ independent of the $\mathrm{pHe}$ and cell type. The drug enhancement ratio (ER) was calculated as the ratio of drug doses yielding a surviving fraction of $10 \%$ in normal cells at pHe 6.8 compared with the drug concentration yielding the same surviving fraction for the various other ( $\mathrm{pH}$ and cell type) experimental conditions. All survival curve experiments were repeated three times; normal and low-pH-adapted cells were concurrently evaluated in each experiment at the same extracellular $\mathrm{pH}$.

\section{Calculation of the predicted intracellular drug concentration}

The measured changes in drug cytotoxicity as a function of the $\mathrm{pH}$ gradient and measured cellular concentration of doxorubicin were compared with the predicted changes in the intracellular (cytoplasmic) concentration of the drug. For doxorubicin, as for a weak base with one ionizing group, the predicted intracellular/extracellular concentration ratio at equilibrium is:

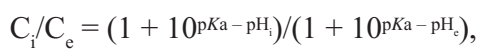

in which $\mathrm{C}_{\mathrm{i}}$ and $\mathrm{C}_{\mathrm{e}}$ are the total (charged plus uncharged) intracellular and extracellular drug concentrations respectively (Roos and Boron, 1981). The $\mathrm{pKa}$ of doxorubicin is approximately 8.2 with remaining $\mathrm{p} K a \mathrm{~s}>9.5$ (Skovsgaard, 1977). 


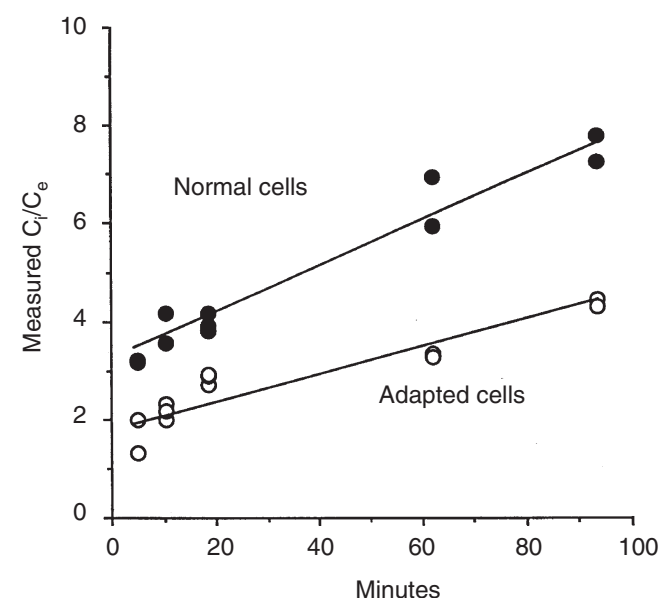

Figure 2 The measured intracellular to extracellular concentration ratio of doxorubicin $(\mathrm{C} / \mathrm{C})$ is plotted as a function of time after doxorubicin addition. The extracellular $\mathrm{pH}$ was adjusted to 6.3 approximately $30 \mathrm{~min}$ before drug addition. Normal and low-pH-adapted cells were analysed concurrently. One data point per sample from two independent experiments

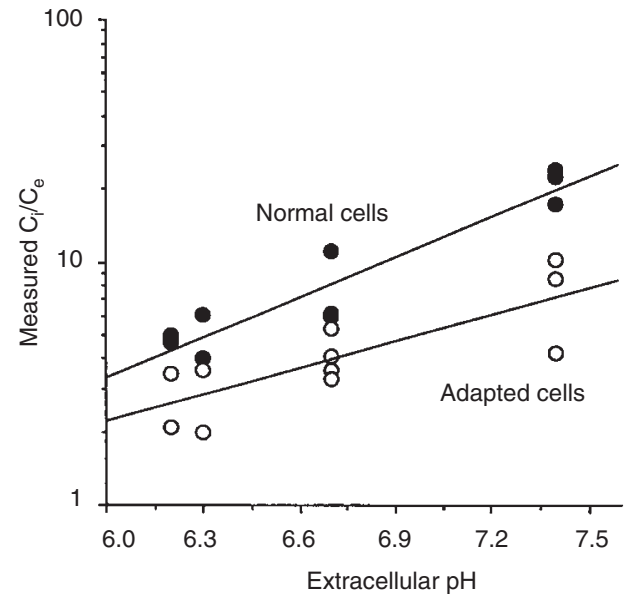

Figure 3 The measured intracellular to extracellular concentration ratio of doxorubicin is plotted as a function of extracellular $\mathrm{pH}$. The drug concentration ratio was measured $90 \mathrm{~min}$ after doxorubicin addition. The results of independent experiments containing two or more pairs of concurrent measurements in normal and low-pH-adapted cells are shown. Extracellular $\mathrm{pH}$ values are $\pm 0.05 \mathrm{pH}$ units

\section{RESULTS}

The relationship between the extracellular $\mathrm{pH}$ and the difference between the intracellular and extracellular $\mathrm{pH}$ for normal and low$\mathrm{pH}$-adapted cells is shown in Figure 1. At extracellular $\mathrm{pH}$ values $>7.1$, the magnitude of the $\mathrm{pH}$ gradient is similar in both cell types, however at $\mathrm{pH}$ values $<7$ the intracellular $\mathrm{pH}$ of cells adapted to low-pH conditions is relatively resistant to extracellular $\mathrm{pH}$ changes and the $\mathrm{pH}$ gradient difference continuously increases. At an extracellular $\mathrm{pH}$ in the range of $6.0-6.4$, the cellular $\mathrm{pH}$ gradient in adapted cells is approximately 0.4 units greater than in their unadapted counterparts.

Changes in the intracellular to extracellular drug concentration ratio at $\mathrm{pH} 6.3$ as a function of time after doxorubicin addition is shown in Figure 2. In both cell types, the cellular drug concentration linearly increases with drug exposure time. Consistent with

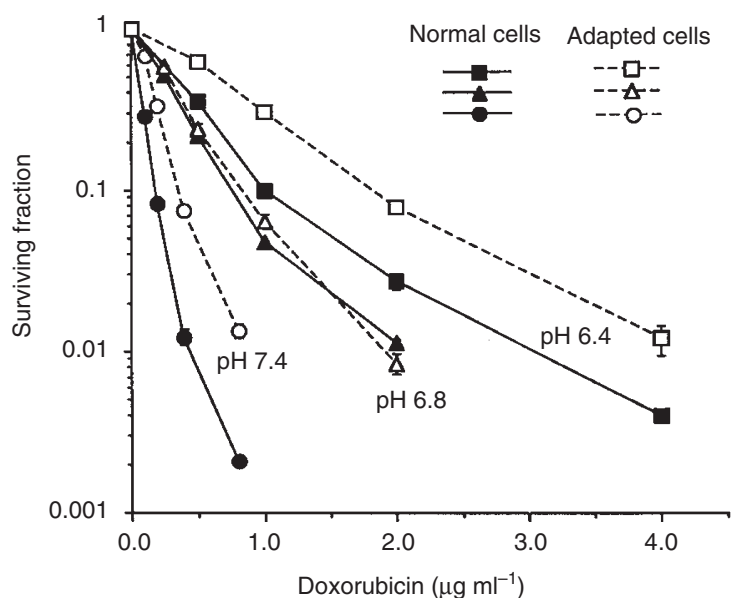

Figure 4 Doxorubicin cell survival curves were measured at extracellular $\mathrm{pH}$ values of $7.4,6.8$ and 6.4 ( $\pm 0.05 \mathrm{pH}$ units). The means and standard errors of three separate experiments are shown. For each experiment, normal and low-pH-adapted cells, at the same extracellular $\mathrm{pH}$, were analysed concurrently

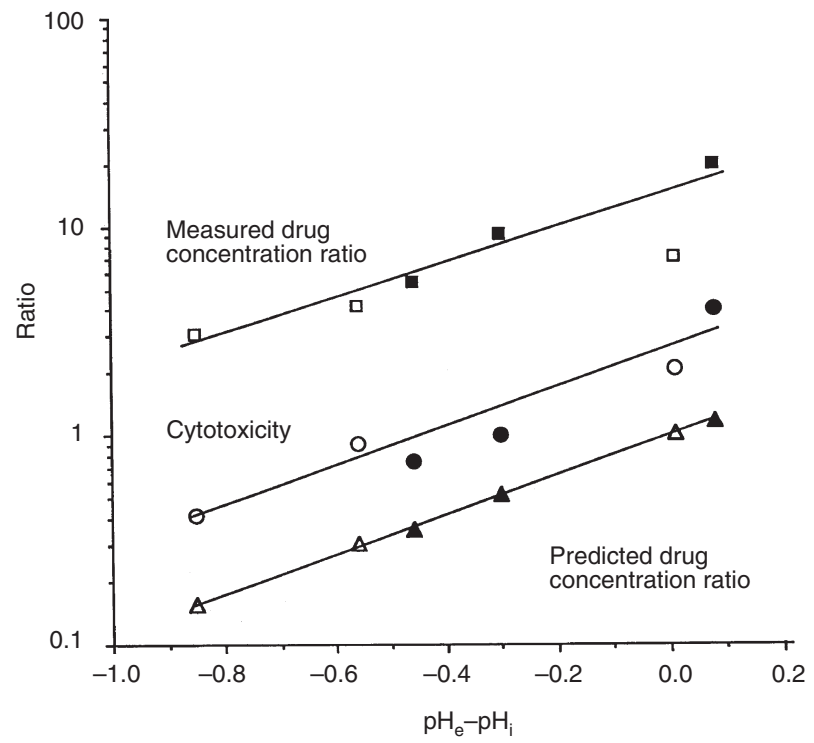

Figure 5 The measured and predicted intracellular to extracellular concentration ratio of doxorubicin, and drug cytotoxicity enhancement ratio, are plotted as a function of the difference between the intracellular and extracellular $\mathrm{pH}\left(\mathrm{pH}_{-}-\mathrm{pH}_{\mathrm{i}}\right)$. The predicted concentration ratio assumes no drug binding or metabolism. The measured concentration ratio is for $90 \mathrm{~min}$ exposure to doxorubicin. Normal cells are indicated by closed symbols; low$\mathrm{pH}$-adapted cells by open symbols

the $\mathrm{pH}$ partition theory, in normal cells for which the intracellular $\mathrm{pH}$ is less alkaline compared with the extracellular compartment, a greater fraction of the weak base is ionized and therefore accumulated in the intracellular compartment. A similar time-dependent linear increase in cellular drug concentration was observed at all extracellular $\mathrm{pH}$ values examined. From experiments similar to those shown in Figure 2, the intracellular to extracellular drug concentration ratio was determined at $90 \mathrm{~min}$, i.e. identical to the drug exposure time for the toxicity assays. The results are shown in Figure 3. Regardless of the extracellular $\mathrm{pH}$, the intracellular doxorubicin concentration is consistently higher in normal than 
adapted cells, although the measured magnitude of this difference varied slightly from experiment to experiment.

The lethal response of cells to doxorubicin at extracellular $\mathrm{pH}$ of values of 6.4, 6.8 and 7.4 is shown in Figure 4. For both normal (solid curves) and low-pH-adapted cells (dashed curves), $\mathrm{pH}$ variation markedly influences toxicity. For example, for a 90-min exposure to $0.5 \mathrm{mg} \mathrm{ml}^{-1}$ doxorubicin, the surviving fraction of normal cells was reduced by a factor of approximately 50 at an extracellular $\mathrm{pH} 7.4$ vs 6.4. At an extracellular $\mathrm{pH}$ of 6.4 and 7.4, low-pH-adapted cells were substantially more resistant to doxorubicin than normal cells.

The drug cytotoxicity enhancement ratio is plotted as a function of the difference between the intracellular and extracellular $\mathrm{pH}$ $\left(\mathrm{pH}_{\mathrm{e}}-\mathrm{pH}_{\mathrm{i}}\right)$ in Figure 5. Normal cells are indicated by closed circles and adapted cells by open circles. The data for both cell types are fitted well by a single curve, indicating that, for both cell types, the cellular $\mathrm{pH}$ gradient is the determinant of variable cytotoxicity.

Two additional curves are shown in Figure 5. The lower curve (triangles) is the expected intracellular/extracellular drug concentration ratio $\left(\mathrm{C}_{\mathrm{i}} / \mathrm{C}_{\mathrm{e}}\right)$ of doxorubicin at equilibrium if the ionized form of the drug is membrane impermeable, the non-ionized form is permeable and the drug is neither sequestered or metabolized. These data are calculated from the equation above. The slope of this curve $(0.94 \pm 0.12)$ is identical to the slope of the measured drug enhancement ratio curve $(0.95 \pm 0.15)$.

The upper curve of Figure 5 is the measured intracellular/extracellular doxorubicin concentration ratio after $90 \mathrm{~min}$ drug exposure. As might be expected (see Discussion section), at a particular $\mathrm{pH}$ gradient, the values of the measured and predicted drug concentration ratios differ. Similar to the results observed with drug toxicity, the data showing the relationship between the $\mathrm{pH}$ gradient and measured intracellular doxorubicin concentration both for normal and low-pH-adapted cells are fitted well by a single curve. The slope of this curve $(0.71 \pm 0.20)$ does not significantly differ from the toxicity and predicted drug concentration ratio curves.

\section{DISCUSSION AND SUMMARY}

The results of this study clearly show that doxorubicin accumulation and toxicity increase with increasing medium $\mathrm{pH}$. $\mathrm{pH}$ variation may exert its drug modifying effect intracellularly, extracellularly or via change in the cellular $\mathrm{pH}$ gradient. The $\mathrm{pH}$-dependent effect is clearly not related to changes in intracellular $\mathrm{pH}$. For both cell types and all $\mathrm{pH}$ conditions, the relationship between $\mathrm{pHi}$ and the measured drug accumulation or toxicity enhancement ratio is poor ( $r^{2}=0.02$ and 0.19 respectively). Whether $\mathrm{pH}$ modification of drug uptake and toxicity is dependent upon the change in extracellular $\mathrm{pH}$ or the $\mathrm{pH}$ gradient is less straightforward. This is because a change in extracellular $\mathrm{pH}$ results in an associated change in the $\mathrm{pH}$ gradient, especially in normal cells.

An analysis of the results obtained from both normal and low$\mathrm{pH}$-adapted cells helps resolve this question. As seen in Figures 2 and 3 , both the rate of accumulation and total accumulation at 90 min clearly differs in normal vs low-pH-adapted cells at the same extracellular $\mathrm{pH}$. Additionally, at a $\mathrm{pH}_{\mathrm{e}}$ of 6.4 , in which the most pronounced gradient difference between normal and low-pHadapted cells occurs, normal cells are substantially more sensitive to doxorubicin than their low-pH-adapted counterparts. This indicates that the $\mathrm{pH}$ gradient and not extracellular $\mathrm{pH}$ is the major determinant of doxorubicin uptake. The relationship between the predicted and observed results are not, however, quantitatively precise. The measured magnitude of the gradient difference in normal vs adapted cells is greater at $\mathrm{pH}_{\mathrm{e}} 6.4>6.8>7.4$. At these extracellular values, the $\mathrm{pH}$ gradient hypothesis predicts that normal cells will be more sensitive (and have greater drug uptake) than adapted cells, and this is observed. However, the measured difference in sensitivity in normal vs adapted cells is less than the predicted difference at a $\mathrm{pHe}$ of 6.8 , and greater than is predicted at a $\mathrm{pH}_{\mathrm{e}}$ of 7.4. Whether this inconsistency is due to a lack of precision in measuring the magnitude of the gradient, cytotoxicity or other variables is unclear. However, it does not appear to be due to changes in intrinsic properties of adapted cells because of prolonged culture at low $\mathrm{pH}$ (e.g. drug membrane permeability).

It is also of note that for a particular $\mathrm{pH}$ gradient value (Figure 5) the measured doxorubicin accumulation (intracellular/extracellular concentration ratio) is substantially greater than the predicted ratio. This is not unexpected because doxorubicin is readily bound and sequestered at various intracellular sites and compartments, especially DNA and lysosomes (Noël et al, 1978; Durand, 1981), and continually accumulates during the 90-min duration of drug exposure. However, because the quantity of drug which accumulates intracellularly is proportional to the quantity of drug which gains access to the intracellular compartment, the numerical value of the measured ratios would change proportionally, leaving the slopes of the curves vs $\mathrm{pH}$ gradient unchanged as is observed.

To summarize, the relationship between changes in $\mathrm{pH}$ and the uptake and toxicity of doxorubicin is well predicted by the $\mathrm{pH}$ partition theory in normal and low-pH-adapted cells. These results further support the suggestion that the design and utilization of weak acid or bases with appropriate $\mathrm{pKas}$ may be expected to enhance cellular uptake of available drug in tumour or normal tissue because of the naturally occurring cellular $\mathrm{pH}$ gradient differences in these tissues (Gerweck and Seetharaman, 1996; Kozin and Gerweck, 1998).

\section{REFERENCES}

Born R and Eicholtz-Wirth H (1981) Effect of different physiological conditions on the action of adriamycin on chinese hamster cells in vitro. Br J Cancer 44 : 241-246

Brophy GT and Sladek NE (1983) Influence of $\mathrm{pH}$ on the cytotoxic activity of chlorambucil. Biochem Pharma 32: 79-84

Chu GL and Dewey WC (1988) The role of low intracellular or extracellular pH in sensitization to hyperthermia. Radiat Res 114: 154-167

Dennis MF, Stratford MRL, Wardman P and Watts ME (1985) Cellular uptake of misonidazole and analogues with acidic or basic functions. Int J Radiat Biol 47: $629-643$

Durand RF (1981) Flow cytometry studies of intracellular adriamycin in multicell spheroids in vitro. Cancer Res 41: 3495-3498

Eicholtz-Wirth H (1980) Dependence of the cytostatic effect of adriamycin on drug concentration and exposure time in vitro. Br J Cancer 41: 886-891

Fellenz MP and Gerweck LE (1988) Influence of extracellular pH on intracellular $\mathrm{pH}$ and cell energy status: relationship to hyperthermic sensitivity. Radiat Res 116: $305-312$

Gerweck LE and Seetharaman K (1996) Cellular pH gradient in tumor versus normal tissue: potential exploitation for the treatment of cancer. Cancer Res $\mathbf{5 6}$ : 1194-1198

Israel M, Pegg WJ, Wilkinson PM and Garnick MC (1978) Liquid chromatographic analysis of adriamycin and metabolites in biological fluids. $J$ Liquid Chromatogr 1: 759-809

Jahde E, Glusenkamp K, Klunder I, Hulser DF, Tietze L and Rajewsky MF (1989) Hydrogen ion-mediated enhancement of cytotoxicity of bis-chloroethylating drugs in rat mammary carcinoma cells in vitro. Cancer Res 49: 2965-2972

Kozin SV and Gerweck LE (1998) Cytotoxicity of weak electrolytes after the adaptation of cells to low $\mathrm{pH}$ : role of the transmembrane $\mathrm{pH}$ gradient. $\mathrm{Br} \mathrm{J}$ Cancer 77: 1580-1585 
Mikkelsen RB, Asher C and Hicks ST (1985) Extracellular pH transmembrane distribution and cytoxicity of chlorambucil. Biochem Pharma 34: 2531-2534

Noel G, Peterson C, Trouet A and Tulkens P (1978) Uptake and subcellular localization of daunorubicin and adriamycin in cultured fibroblasts. Eur J Cancer 14: 363-368

Roos A and Boron WF (1981) Intracellular pH. Physiol Rev 61: 296-434

Schwartz HS (1973) A fluorometric assay for daunomycin and adriamycin in animal tissues. Biochem Med 7: 396-404

Skarsgard LD, Skwarchuk MK, Vinczan A, Kristl J and Chaplin DJ (1995) The cytotoxicity of melphalan and its relationship to $\mathrm{pH}$, hypoxia and drug uptake. Anticancer Res 15: 219-224
Skovsgaard T (1977) Transport and binding of daunorubicin, adriamycin, and rubidazone in Ehrlich ascites tumour cells. Biochem Pharma 26: 215-222

Tritton TR and Yee G (1982) The anticancer agent adriamycin can be actively cytotoxic without entering cells. Science 217: $248-250$

Vaupel P, Kallinowski F and Okunieff P (1989) Blood flow, oxygen and nutrient supply, and metabolic microenvironment of human tumors: a review. Cancer Res 49: 6449-6465

Waddell WJ and Butler TC (1959) Calculation of intracellular $\mathrm{pH}$ from the distribution of 5,5-dimethyl-2,4-oxazolidinedione (DMO). Application to skeletal muscle of the dog. J Clin Invest 38: 720-729 